\title{
Pemberdayaan Ekonomi Masyarakat Melalui Pendirian Baitul Maal wa Tamwil Padamulya
}

\section{Community Economic Empowerment Through Establishment of Baitul Maal wa Tamwil Padamulya}

\author{
M. Nasrullah Ridwan ${ }^{1}$ \\ ${ }_{1}^{1}$ Program Studi Perbankan Syariah, Fakultas Ekonomi Islam, Universitas Djuanda Bogor, Jl. Tol Ciawi No. 1, \\ Kotak Pos 35 Ciawi, Bogor 16720, e-mail: nasrullahridwan17@gmail.com
}

(Diterima: 20-12-2020; Ditelaah: 12-04-2021; Disetujui: 30-10-2021)

\begin{abstract}
Abstrak
Baitul Maal Wat Tamwil (BMT) sebagai Lembaga Keuangan Mikro Syariah yang menawarkan solusi bagi masyarakat Desa Padamulya untuk mengurangi penggunaan lembaga jasa pinjaman berbasis riba yang sampai saat ini masih digunakan masyarakat desa tersebut. Masyarakat menggunakan pinjaman berbasis riba karena tidak adanya fasilitas lain dan terdesak oleh kebutuhan walaupun masyarakat sudah mengetahui haramnya riba. Realitas permasalahan ekonomi Desa Padamulya terdapat pada kurangnya pengetahuan masyarakat tentang lembaga keuangan Islam salah satu faktornya adalah tidak ada lembaga keuangan syariah yang terdapat di Desa Padamulya. Pilihan yang ditawarakan untuk menyelesaikan permasalahan tersebut adalah dengan membentuk lembaga keuangan syaraiah atau BMT di Desa Padamulya Kecamatan Pasirkuda Kabupaten Cianjur. Target yang ingin dicapai setelah terbentuknya BMT Padamulya menjadi jalan masyarakat dalam menyelesaikan masalah perekonomian juga sebagai pendorong ekonomi masyarakat yang memiliki usaha untuk lebih dikembangkan.
\end{abstract}

Kata kunci: BMT, Ekonomi Syariah, Pemberdayaan, Pinjaman, Solusi

\begin{abstract}
Baitul Maal Wat Tamwil (BMT) as an Islamic microfinance institution that offers solutions for the people of Padamulya Village to reduce the use of usury-based loan service institutions that are still used by the village community. This does not mean that people do not know the law regarding the use of usury assets, but because of urgent needs and there are no other options so that people continue to use the loan services. The reality of the economic problems of Padamulya village lies in the lack of public understanding of Islamic financial institutions. One of the factors is that there is no Islamic financial institution in Padamulya village. The solution offered to resolve the problem is to establish a sharia financial institution or BMT in Padamulya village, Pasirkuda district, Cianjur regency. The target to be achieved after the formation of Padamulya BMT is a community solution in solving economic problems as well as encouraging people who have businesses to be further developed.
\end{abstract}

Keywords: BMT, Empowerment, Loans, Sharia Economy, Solutions

\section{PENDAHULUAN}

BMT atau Baitul Mal Wa Tamwil diambil dari dua kata yang berbeda, yaitu: Baitul Maal (rumah uang) dan Baitul Tamwil (rumah pembiayaan). Untuk itu dapat dipahami bahwa BMT merupakan lembaga keuangan syariah yang memiliki dua fungsi, yaitu Baitul Maal (Lembaga Sosial) dan Baitul Tamwil (Lembaga Komersial). Oprasional yang dilakukan BMT dari kedua fungsi tersebut adalah sama-sama menghimpun dana masyarakat dan menyalurkannya kepada masyarakat, akan tetapi jenis dana yang dihimpun dan disalurkannya berbeda. BMT dioprasikan oleh prinsip berbagi untuk menumbuhkan dan 
mengembangkan usaha mikro serta meningkatkan martabat dan pendapatan orang yang tidak mampu (dhuafa) (Aziz, 2006).

Sebagai Baitul Maal dana yang dihimpun BMT adalah dana ZISWAF (Zakat, Infak, Shodaqoh dan Wakaf). Setelah dihimpun dana tersebut disalurkan kepada masyarakat yang berhak menerimanya, baik secara konsumtif ataupun produktif. Sedangkan sebagai Baitul Tamwil, BMT menghimpun dana simpanan masyarakat seperti tabungan dan investasi serta menyalurkan dana-dana tersebut dalam bentuk pembiayaan tertentu. Hal ini berfungsi untuk memperdayakan ekonomi masyarakat dan memenuhi kebutuhan konsumtif masyarakat. Dengan demikian, BMT memiliki dua peran utama, yaitu untuk mengangkat dan memperdayakan kaum fakir melalui instrument ZISWAF (Zakat, Infak, Shadaqoh dan Wakaf) dan untuk memperdayakan ekonomi masyarakat supaya lebih produktif dalam setiaf kegiatan ekonomi, baik dengan cara menabung ataupun usaha. (Alhifni, 2018: 21; Nofiaturrahmah, 2015: 283; Lubis, 2016: 274).

Perencanaan inisiasi pembentukan Baitul Mal Wat Tamwil (BMT) merupakan proses pembelajaran bagi mahasiswa yang dikembangkan melalui bentuk kegiatan pengabdian kepada masyarakat dalam berbagai segi kehidupan bermasyarakat. Bentuk pengabdian tersebut dilaksanakan dengan cara menerapkan ilmu pengetahuan yang sudah diperoleh di perkuliahan kepada masyarakat. Ilmu pengetahuan yang diterapkan adalah ilmu pengetahuan yang diperlukan oleh masyarakat atau yang dapat menjadi solusi bagi permasalahan yang terjadi dikehidupan masyarakat. Pelaksanaan Program ini ditujukan untuk menumbuh kembangkan empati dan kepedulian terhadap berbagai permasalahan yang riil dihadapi masyarakat terutama bidang ekonomi dan pengembangan yang diperlukan untuk mencerdaskan kehidupan bangsa dan mewujudkan kesejahteraan masyarakat yang sesuai dengan masyarakat Islam yang sebenar-benarnya.

Program inisiasi pembentukan BMT merupakan tugas wajib mahasiswa agar mampu mewujudkan apa yang telah difokuskan untuk mencapai tujuan utama yang telah ditentukan tersebut. Inisiasi pendirian LKMS merupakan kegiatan dalam memperkenalkan sistem ekonomi syariah kepada masyarakat. Sosialisasi merupakan salah satu cara yang paling tepat untuk memberikan pemahaman kepada masyarakat mengingat pentingnya ekonomi Islam untuk dipahami oleh setiap kalangan masyarakat. Oleh karena itu peran penting dari sosialisasi ekonomi syariah agar masyarakat bisa mengetahui manfaat dari mengenal ekonomi syariah.

Adapun lokasi yang dijadikan tempat pelaksanaannya adalah Desa Padamulya, Kecamatan PasirKuda, Kabupaten Cianjur, Provinsi Jawa Barat. Alasan dipilih Desa Padamulya adalah karena kategori desa tersebut merupakan desa yang memiliki potensi baik di bidang pendidikan, keagamaan, sosial budaya, sarana prasarana, dan bidang ekonomi sehingga memerlukan banyak bantuan dalam hal ide dan gagasan yang dapat memajukan desa tersebut. Terutama bidang ekonomi yang dimana masyarakat disana menginginkan adanya Lembaga Keuangan Mikro Syariah (LKMS). 
Selama ini masyarakat menggunakan jasa keuangan yang berdasarkan bunga atau Rentenir oleh karena itu masyarakat desa Padamulya sangat mengaharapkan adanya pengembanan potensi-potensi yang terdapat pada desa tersebut. Dengan adanya program ini sasaran utamanya adalah masyarakat yang membutuhkan dana untuk berbagai macam keperluan dan kebutuhan baik masyarakat kalangan atas maupun kalangan bawah. Tidak hanya itu, para petani bisa menjual hasil kebun nya ke BMT kemudian dari hasil penjualan tersebut akan disimpan dan bisa diambil kapanpun ketika membutuhkan. Bahkan setiap lembaga yang ada disana seperti lembaga pendidikan (TK, SD, SMP, SMA) dan juga Pondok Pesantren bisa melakukan kerjasama mengatur keuangan seperti siswa/siswi diarahkan dan biasakan untuk menabung di BMT sehingga ketika ada biaya yang harus dibayar tidak lagi kesulitan hanya tinggal tarik tunai.

Sumber daya alam yang dimiliki Desa Padamulya belum sepenuhnya dikembangkan oleh masyarakatnya, sehingga perlu adanya bimbingan atau pendampingan kepada masyarakat untuk memanfaatkan potensi yang ada. Berdasarkan observasi yang kami lakukan hampir semua masyarakat memiliki keahlian dari mulai menjahit, manganyam, membuat produk makanan khas daerah, dan membuat karajinan dari bahan yang tidak digunakan. Namun permasalahnya adalah kurangnya modal untuk mengembangkan potensi tersebut. Sehingga diharapkan dengan adanya BMT di desa tersebut permasalahan itu bisa teratasi dan potensi itu bisa menjadikan solusi dalam penguatan ekonomi masyarakat.

\section{METODE PELAKSANAAN}

Rencana kegiatan merupakan perencanaan yang dilakukan penulis terhadap program inisiasi pendirian LKMS yang dilakukan pada tahun 2019 di Desa Padamulya. Adapun rencana kegiatan tersebut menggunakan metode pendekatan melalui pertemuan yang direncanakan. Adapaun perencanaannya adalah sebagai berikut:

a. Melakukan kerjasama dengan Kepala Desa Padamulya, untuk memperlancar dalam perencanaan program inisiasi pendirian LKMS ini.

b. Memberikan solusi melalui sosialisasi pentingnya LKMS bagi masyarakat Desa Padamulya.

c. Mengatasi permasalahan yang dihadapi masyarakat terutama bagi warga yang sudah lama terjerat dalam praktik ribawi.

d. Mengajak kepada masyarakat untuk menjalankan syariat Islam melalui inisiasi pendirian LKMS.

e. Membentuk struktur organisasi kepengurusan BMT, Logo perusahan, AD-ART dan kebutuhan lainnya.

\section{HASIL \& PEMBAHASAN}

Kegiatan inisiasi pendirian LKMS di Desa Padamulya, Kecamatan Pasirkuda, Kabupaten Cianjur, Provinsi Jawa Barat adalah sebagai koordinator atau penanggungjawab dalam 
program inisiasi pendirian LKMS dari perwakilan setiap kelompok. Hasil dari kegiatan ini adanya bukti fisik lembaga keuangan syariah BMT Padamulya.

Munculnya lembaga keuangan BMT ini unttuk memberikan alternative kepada masyarakat kalangan bawah dalam mendapatkan pembiayaan dengan kewajiban pengembalian yang cukup ringan. Sehingga masyarakat tidal lagi meminjam kepada rentenir lagi. Dengan adanya BMT dalam memberikan pembiayaan dengan akses yang mudah iini diharapkan bisa menghapuskan praktik rentenir di masyarakat (Dwi \& Kurnia, Juni 2015).

\section{Pelaksanaan Kegiatan}

Sebagai tahap awal pelaksanaan, dosen dan mahasiswa melakukan perencanaan tentang inisiasi pendirian Lembaga keuangan Mikro Syariah di Desa Padamulya. Perencanaan yang dilakukan oleh mahasiswa dengan dosen melalui kegiatan diskusi yang membahas program Inisiasi Lembaga Keuangan Mikro Syariah adalah program semua kelompok.

Perencanaan selanjutnya perkumpulan semua kelompok untuk menentukan perwakilan setiap kelompok sebagai Penanggung Jawab (PJ) program Inisiasi Lembaga Keuangan mikro syariah. Adapun pembahasan pada rapat PJ membahas tentang pendirian BMT dari mulai tahap pertama sampai pada tahap peresmian kemudian menentukan pihak-pihak yang dilibatkan. Dalam hal ini, tahapan yang dilakukan adalah membentuk struktur panitia pelaksana pembentukan BMT Padamulya, adapun struktur kepanitiannya adalah:

\begin{tabular}{ccl}
\multicolumn{3}{c}{ Tabel 1. Panitia Pelaksana Pembentukan BMT Padamulya } \\
\hline NO & Jabatan & \multicolumn{1}{c}{ Nama } \\
\hline 1 & Ketua & Ihsan Ginanjar., SEI \\
\hline 2 & Sekretaris & Siti Sovia Anwar \\
\hline 3 & Bendahara & Hilwa \\
\hline 4 & Kordinator & 1. M. Nazib Alfarizi \\
& Lapangan & 2. M. Nasrullah Ridwan \\
& & 3. D.M. Lukman Nurkarim \\
& & 4. M. Rangga Ardiansyah
\end{tabular}

Pembahasan selanjutnya menentukan pihak-pihak yang dilibatkan dalam pendirian BMT Padamulya diantaranya Aparatur Desa Padamulya, Tokoh Agama (MUI), Tokoh Masyarakat (RT, RW, KADUS), kelompok Pemberdayaan Kesejahtraan keluarga (PKK), Perwakilan seluruh Dewan Kemakmuran Masjid (DKM) yang ada, dan organisasi lainnya.

Pada tanggal 12 Agustus 2019 melakukan Rapat kerja (Raker) yang dilaksanakan di kantor desa Padamulya bersama bapak kepala desa beserta jajarannya, membahas 
tentang penyampaian rencana desa oleh bapak Parno S.I.P. (Kepala Desa) kemudian penyampaian rencana program pembentukan Lembaga keuang Mikro Syariah (LKMS) oleh mahasiswa, sebelum membahas tentang rencana program mahasiswa memperkenalkan LKMS mahasiswa menyampaikan studi kasus yang terjadi di masyarakat. Tanggapan atau respon Bapak kepala desa sangat mendukung dengan adanya program pendirian LKMS. Adapun rencana yang disampaikan oleh mahasiswa dalam melaksanakan program tersebut diantaranya mengadakan rapat besar dengan tokoh masyarakat kemudian membentuk struktur kepengurusan dan menentukan lokasi kantor.

Setelah diskusi tersebut dilakukan, mahasiwa mempersiapkan materi untuk disampaikan kepada masyarakat pada acara rapat besar. Sedangkan pihak desa Padamulya membuat dan menyebarkan surat undangan kapada masyarakat untuk acara rapat besar yang diadakan di desa Padamulya. Adapun meteri yang akan disampaikan diantaranya; 1) Pengertian, manfaat, tujuan LKMS. 2) Contoh Sukses dan simulasi pembiayaan di lembaga keuangan syariah. 3) Target LKMS. 4) Struktur Organisasi LKMS. Setelah pembagian materi selesai dilanjutkan pada pembahasan penentuan anggaran dan kebutuhan yang diperlukan untuk pendirian LKMS.

Pada tanggal 24 Agustus 2019 malaksanakan kegiatan rapat besar di desa Padamulya dengan Aparatur Desa Padamulya, Tokoh Agama (MUI), Tokoh Masyarakat (RT, RW, KADUS), kelompok Pemberdayaan Kesejahtraan keluarga (PKK), Perwakilan seluruh Dewan Kemakmuran Masjid (DKM) yang ada, dan organisasi lainnya. Menindak lanjuti setelah kegiatan rapat besar, panitia persiapan mengadakan perkumpulan untuk membentuk kepengurusan, nama lembaga, visi dan misi, logo lembaga, AD-ART, banner presmian dan logistik yang diperlukaan untuk kegiatan oprasional.

Rapat pada hari Senin tanggal 27 Agustus 2019 yang membahas mengenai pembentukan LKMS. Dari rapat tersebut disepakati akan didirikannya LKMS dalam bentuk BMT, yaitu dengan nama BMT Padamulya serta dirancangnya visi-misi, logo dan struktur kepengurusan. Ketua BMT Padamulya ini adalah Bapak Ikhsan Ginanjar SEI. Peresmian BMT Padamulya dilaksanakan pada hari Kamis tanggal 5 September 2019 di Gedung Dwimulya Desa Padamulya yang diresmikan oleh Kepala Desa Padamulya yaitu Bapak Parno S.I.P.

\section{Evaluasi dan Monitoring}

Keberhasilan kegiatan ini adalah adanya berdirinya lembaga keuangan syariah BMT Padamulya dan keberlanjutan oprasional BMT. Keseriusan dari pengurus BMT akan menentukan berjalan atau tidaknya oprasional BMT Padamulya kemudian peran lembaganya untuk memperdayakan ekonomi masyarakat tidak akan optimal karena diperlukan secara intensif, dan juga dukungan dari masyarakat. (Sagara, Pratama :2016).

Partisipasi dalam kegiatan ini sebagian besar masyarakat sangat antusias dibentuknya lembaga keuangan syariah di desanya, dengan begitu pendekatan dengan cara perkumpulan langsung memberi kesempatan yang lebih banyak masyarakat untuk melakukan diskusi dan saling bertukar informasi. Adapun Fungsi Monitoring sebagai 
berikut: Compliance (kesesuaian/kepatuhan) menentukan kesesuaian implementasi kebijakan dengan standard dan prosedur yang telah ditentukan; Auditing (pemeriksaan) menentukan ketercapaian sumber-sumber/pelayanan kepada kelompok sasaran (target groups).

Adapun indikator ketidakcapaian dari kegiatan ini yaitu belum adanya sistem teknologi keuangan yang bagus dikarenakan kebutuhan anggaran untuk pengadaan teknologi keuangan tersebut cukup mahal oleh karenanya BMT Padamulya masih menggunakan sistem keuangan yang tidak berbayar. Ketersediaan barang-barang kantor yang belum lengkap sehingga masih menggunakan barang yang ada dan masih bisa digunakan. Belum ada pelatihan khusus untuk pengurus BMT Padamulya dalam menjalankan tugas pokok dan fungsinya.

\section{Indikator Hasil dan Manfaat}

Hasil dan manfaat dari adanya program ini antara lain masyarakat sudah memiliki peningkatan pengetahuan tentang lembaga Keuangan Mikro syariah (LKMS) dan susksesnya BMT Padamulya dengan adanya peningkatan-peningkatan dari berbagai aspek.

\section{Tabel 2. Capaian Program}

\begin{tabular}{clcc}
\hline NO & \multicolumn{1}{c}{ Keterangan } & $\begin{array}{c}\text { Pasca } \\
\text { Pelaksanaan }\end{array}$ & $\begin{array}{c}\text { Pra } \\
\text { Pelaksanaan }\end{array}$ \\
\hline 1 & $\begin{array}{l}\text { Pengetahuan masyarakat mengenai pemahaman } \\
\text { manfaat ekonomi Islam }\end{array}$ & $50 \%$ & $80 \%$ \\
2 & $\begin{array}{l}\text { Minat masyarakat dalam mengembangkan } \\
\text { kegiatan perekonomian terutama hal yang } \\
\text { berbasis ekonomi syariah } \\
\text { Lembaga keuangan syariah BMT yang terdapat di } \\
\text { desa Padamulya }\end{array}$ & $40 \%$ & $70 \%$ \\
\hline $\begin{array}{l}\text { Kesadaran masyarakat tentang pentingnya } \\
\text { Lembaga Keuangan Syariah }\end{array}$ & $50 \%$ & $80 \%$ \\
\hline
\end{tabular}

\section{Masalah yang Dihadapi}

Sebagai penanggungjawab, penulis merencanakan kegiatan inisiasi pendirian LKMS berjalan dengan lancar. Berjalannya kegiatan ini tidak lepas dari beberapa pihak yang telah membantu untuk kesuksesan kegiatan ini, seperti para dosen pembimbing, seluruh mahasiswa, kepala desa Padamulya dan seluruh masyarakat yang telah banyak membantu. Inisiasi pendirian LKMS berjalan sesuai dengan harapan semua pihak.

Akan tetapi rencana kegiatan yang telah dirancang ketika sampai di lokasi penulis harus menyesuaikan program kerja dengan keadaan yang ada di Desa Padamulya. Hal ini menjadikan program yang dilaksanakan mendapatkan hambatan-hambatan, sehingga berdampak terhadap pelasanaan kegiatan sosialisasi.

Adapun masalah yang di jumpai selama kegiatan inisiasi pendirian LKMS berlangsung di antaranya: 
1. Sulitnya menyesuaikan waktu dalam pelaksanaan program.

2. Masih kurangnya SDM yang memenuhi kriteria untuk menjadi pengurus BMT Padamulya.

\section{KESIMPULAN}

Kegiatan yang penulis lakukan berjalan dengan lancar dari perencanaan, perizinan dan waktu pelaksanaannya. Sebagian Masyarakat pun merespon dengan baik program ini. Dengan diresmikannya BMT Padamulya diharapkan dapat meningkatkan kemampuan masyarakat dalam bidang ekonomi syariah sehingga masyarakat dapat mengembangkan potensi ekonomi yang ada di wilayah tersebut. Juga menjadi solusi untuk mengurangi penggunaan jasa pembiayaan berbasis riba atau rentenir yang selama ini masih digunakan di desa tersebut. Program kegiatan ini diharapkan terus berlanjut dengan cara adanya koordinasi masyarakat dengan penulis agar pengetahuan masyarakat tentang ekonomi syariah terus bertambah sebagai bahan masyarakat dalam menggunakan LKMS yang sudah dibentuk di Desa Padamulya.

\section{DAFTAR PUSTAKA}

Ayogi, V. D., \& Kurnia, T. (2015, Juni). Optimalisasi Peran BMT dalam Upaya Penghapusan Praktik Rentenir. Jurnal Syarikah, Vol. 1 No. 1, Pp 1.

Dewi,S.H.,M.H, N. (2017, Februari-Juli). Regulasi Keberadaan BMT dalam Sistem Perekonomian di Indonesia. Jurnal Serambi Hukum, Vol. 11 No. 1, Pp. 96-97.

Gayo, A. A., \& Taufik, I. A. (2012, Agustus). Kedudukan Fatwa DSN-MUI dalam Mendorong Perkembangan Bisnis Perbankan Syariah (Perspektif Hukum Perbankan Syariah). Jurnal Rechtsvinding (Media Pembinaan Hukum Nasional), Vol. 1 No. 2, Pp. 262.

Hidayah, A. N., \& Kartini, I. A. (2016). Peranan Bank dalam Sosialisasi dan Edukasi Masyarakat tentang Kemanfaatan Produk dan Jasa Perbankan Syariah. Jurnal Kosmik Hukum, Vol. 16 No. 1, Pp. 75.

Jenita. (2017, Desember). Peran Lembaga Keuangan Mikro Syariah dalam Pemberdayaan Ekonomu Masyarakat Kecil Menengah. Jurnal Lembaga Keuangan dan Perbankan, Vol. 2 No. 2, Pp. 3.

Khadijah S, Saleh NEP, Kamarudin MF, Haryadi A. 2013. Sustainability of Islamic Micro Finance Institutions (IMFIs). Journal of Accounting and Finance. DOI. 10.13189/ujaf.2013.010205

Kusmanto, Y. T. (2014). Pengembangan Ekonomi Islam Berbasis Kependudukan di Perdesaan. Jurnal Ilmu Dakwah, Vol. 34 No. 2, Pp. 232. 
Ridwan

Pemberdayaan Ekonomi Masyarakat melalui Pendirian BMT Padamulya

Lasmiatun. (2017). Peran dan Kebijakan Pemerintah melalui LKM/LKMS untuk Menciptakan Kesejahteraan dan Keadilan Distributif. Jurnal Dimensi, Vol. 10 No. 2, Pp. 41.

Ridwan, A. Hasan. (2013). Manajemen Baitul Mal wa Tamwil. Bandung: Pustaka Setia. 